\title{
Reconsidering the case study method in management education
}

\author{
Christopher Orpen \\ Deakin University, Victoria, Australia
}

This paper argues that recent criticisms of the case study method are not well-founded and that, on the contrary, there are good reasons why it should be a major, or even the dominant, mode of instruction at business schools. As a method, case studies possess a number of distinct advantages over lectures/tutorials in helping students acquire those practical skills in diagnosing and solving problems that serve to distinguish effective from ineffective managers. It is the case study method which also serves to distinguish management from other subjects and gives it the coherence it needs to be regarded as a discipline in its own right. It is argued that for these reasons the current swing away from the case study method at many business schools should be reversed.

S. Afr. J. Bus. Mgmt. 1982, 13: 61-66

Hierdie artikel bespreek onlangse kritiek op die gevallestudiemetode en toon aan dat dié kritiek ongegrond is; daar is inteendeel goeie redes waarom dit 'n belangrike, of selfs die dominante, onderrigmetode by sakeskole moet wees. Gevallestudies het verskeie besliste voordele bo lesings/besprekings as metode om studente te help om daardie praktiese vaardighede in diagnosering en probleemoplossing te ontwikkel wat doeltreffende bestuurders van ondoeltreffendes onderskei. Die gevallestudiemetode dien ook om die bestuurswese van ander vakke te onderskei, en gee aan bestuurstudies die samehangende verband wat dié veld vestig as 'n dissipline in eie reg. Daar word geredeneer dat, om hierdie redes, die huidige swaai weg van die gevallestudiemetode wat by baie sakeskole voorkom, omgekeer behoort te word.

S.-Afr. Tydskr. BedryfsI. 1982, 13: 61-66
The case method is regarded by many management teachers, and quite a few managers themselves, as being out of date. Judging from recent comments, many of them feel that teaching management through cases is an old-fashioned way of doing it, and one that has been superseded by far better ways. Their sentiments are aptly summed up in the following remark from the recent head of the School of Business at the University of Chicago: 'The case method is only the culmination of the rudimentary stage of professional education for business administration - the apprenticeship method'.

The present article is an attempt to offer a rebuttal of this point of view. Its main claim is that the case study method, far from being out of date, possesses special virtues that make it one of the more important means or ways of teaching management. It is the task of this article to explain why this is so.

\section{History of the case method}

The first point to note is that the critics of the case study method are quite right in claiming that it is an old method. The first cases in management were written before the First World War, and the first casebook was published as far back as 1920 . To an important extent, those initial attempts to employ the case study method arose as a way for the new and untried Business School at Harvard University to compete for resources and students with the already highly-successful and prestigious Law School. For instance, it was thought by the School's second dean, a lawyer by training, that business cases could be written which would, over time, contribute a body of precedent for managerial action analogous to legal decisions reached in the courts. For our present purposes, the important point is that the case method still remains a very popular and widely-used method, and not only at the Harvard Business School where, in the words of a recent brochure, it is 'the basic mode of instruction'. Perhaps this is because Harvard has a vested interest in continuing a mode of instruction which they originated. However, should the method be inferior to or worse than more recent methods, one would expect either that Harvard would have swung to these better methods or, failing this, that its standing would have declined, because it was teaching its students by an inferior or poorer method than its competitors. Neither has occurred. As recent surveys have shown, 
Harvard continues to be regarded as one of the best of the American business schools, attracting some of the most able and most intelligent students and staff. And, as shown earlier, it continues to require its students to spend most of their time 'working' their way 'through' a large number of business cases, sometimes over a hundred per semester, covering a variety of topics.

Nevertheless, despite the fact that the case method is still widely used, apart from Harvard, Stanford, Dartmouth and Cape Town and UNISA in South Africa, it does not appear to be the dominant mode of instruction at most business schools. Judging from a fairly thorough examination of business school catalogues, there is still a major reliance on the lecture/tutorial/seminar system, essentially similar to that practised over the years in university arts or science departments. Most of the American, Australian, British and, in my opinion, South African business schools belong to this mainstream. Starting in the sixties a new set of educational tools have become available to teachers of management, including sensitivity groups, role plays, grids and business games, most of which can perhaps be subsumed under the heading of 'experiential exercises'. Although many of these tools or exercises are quite widely used, as a group they have, in my opinion, not yet attained the status of a third-stream approach comparable to either lectures or cases.

One of the main reasons for the early emphasis on cases was that the traditional lecture/seminar/tutorial system was felt to be inadequate to meet the needs of management education. While the lecture may have special advantages in helping a large number of students to master the generalizations of a particular discipline, it has long been recognized that it is a pretty useless way of getting students to operationalize this knowledge. This becomes a critical deficiency when, as in management, the concern is not just whether students have absorbed what they have been taught, but rather whether they take more effective actions on the basis of what they have learnt. The aim of management education has always been the practical one of making students better managers; it has never been one of merely extending or enlarging what they know.

This is because, as indicated earlier, effective management requires a lot more than just the possession of certain information, no matter how valid or coherent it may be. Firstly, managers need to be regarded by their subordinates as leaders, persons they are prepared to follow. For this to occur, managers must possess certain personal qualities that are appropriate for their particular situation, that may have little or nothing to do with the possession of knowledge or information as such, even if it is relevant to the problem at hand. ${ }^{1,2,3}$ Secondly, managers must be able to quickly and accurately diagnose situations and the people in them. Without this capacity, they are unlikely to be really effective, no matter how much formal training they have undergone. As we all know from our own experience, we are dealing here with a talent or skill that cannot be 'taught' by passing on 'information' to people; it is something that can only be learnt by practice, and even then it is something that some people can do better without training than others can do with it. $4,5,6$

\section{Usefulness of theory and generalizations}

There is even some doubt whether the generalizations that can be taught in lectures are of any real use to the aspirant or practising manager. A number of critics have argued that there are no general laws or wide-ranging principles to teach students that will result in them becoming successful managers, thus leaving the casestudy method as the only alternative - by default so to speak. If there is nothing of any value that can be taught in lectures, then we have to rely on the experience of do. ing cases to bring about what it is that improves one's chances of being an effective or successful manager.

For instance, critics say that a major problem with generalizations for managers is that, by their very nature, they abstract from instances and necessarily deal with just a few of the many variables that constitute even a single instance, whereas every manager has to deal with concrete problems that require for their solution the effective integration of all the variables that contribute to the particular problem, and make it what it is. If a manager relied on a particular generalization it is likely he or she would take just some of these variables into account, those included in the generalization; and fail to take others that may be more important into account, those excluded from the generalization - with disastrous consequences.

It is also argued that, unlike scientific research, all that management research can indicate are a few of the necessary conditions for the occurrence of any particular event. Since it cannot provide both the necessary and sufficient conditions, its generalizations cannot be used to make accurate predictions. The best that can be done is to indicate what may happen if certain conditions prevail. But this is worse than useless for the practicing manager, as it is always possible that predictions based on generalizations may be wrong. There is always the chance that some other condition will override the few, usually, just one or two, that constitute the generalization, to make the prediction go astray. For these reasons, it is much better, say critics, not to turn to any so-called generalizations, but rather to rely on one's own careful and detailed reading of the situation - something encouraged by the case study method.

Another difficulty with the law-like generalizations taught in lectures is that they are based on research that is seriously deficient in at least two respects. For one thing, unlike scientific research, the findings from management research depend not only on what is being researched, but also on the investigator and his values. Moreover, there is no clear-cut way of disentangling those two effects from each other, leaving it unknown just how much of what is found is owing to subtle and insiduous biases or preferences on the part of the investigator. For another, there are very few, if any, instances of research findings being replicable, it being very much the exception to find similar studies coming up with similar findings. Moreover, an examination of those few cases where repeatable findings appear to exist, show that they typically deal with trivial or simple things that we all know to be the case anyway.

A further problem with the generalizations students are expected to learn is that, in the nature of things, they usually need to be substantially revised or modified by 
students in order to be applicable to any concrete situation. In view of the endless variety and immense complexity of the kinds of situations encountered by managers, it cannot be otherwise. Unfortunately, there is nothing in the generalizations to inform managers exactly how and when such revisions are to be made, or even when differences are of such a magnitude that the managers are no longer dealing with the same generalization at all. Finally, it is argued that the manager typically needs to understand a situation first in order to know which of many generalizations is applicable, and that this tends to make the generalization redundant or unnecessary. The whole point of a law-like generalization is to help managers understand particular situations, but if helpfulness depends on the situation being initially understood, it is difficult to see what the manager can gain from the generalization.

\section{The use of case studies}

That the case study method must play the major role in management education is principally owing to the fact that it solves these two sets of problems. As regards the first set of problems about the application of concepts and notions to real-life situations, it overcomes the difficulties to which we have alluded by constantly forcing students to confront problems with concepts/ ideas and ideas/concepts with problems, as they go about the job of working out what to do in each case. As regards the second set of basic problems about the status of the law-like generalizations put forward by management researchers, it overcomes them by simply not trying to teach students any such generalizations at all, leaving it to them to develop their own skills and talents by 'working through' a host of real-life problems. Before going on to examine what is involved here in more detail, it is necessary at this stage to clear up three common misunderstandings about cases.

First, there is the failure to distinguish clearly between the kind of classroom case we are considering here, and the research case study, often employed in the social sciences. The main reason for this confusion is that both types of cases originate in an empirical investigation of a single situation, and it is possible for a single research project to yield both a research case study and a classroom case study. But there the similarities end.

Secondly, on the one hand, the research case is intended as a contribution to knowledge of a general kind, extending beyond the particular problem itself. When dealing with such cases, an attempt is usually made to evaluate and interpret the data from the case in the light of data from other cases. An audience of professionals with the same interest in developing wide-ranging laws or principles within a given discipline is typically assumed for research cases. On the other hand, the kind of classroom case employed at business schools is intended to be a vehicle for discussion and skills improvements, not for developing generalizations. No comparison with the findings of other analysts is presented in the written case.

Finally, in contrast to the research case, the methodology to be employed in gathering and evaluating data is, quite deliberately, not made explicit. The emphasis, instead, is on laying out the case in an unadorned manner, with little or no clues or signs as to how various data should be interpreted. These are important features that not only separate the classroom case from the research case, but help to make the case as much like the sort of situation likely to be encountered by managers in their working lives as possible.

These three characteristics are important in classroom cases because in his work the manager must necessarily interpret and weigh facts, behaviour, attitudes, and opinions for himself. It is precisely because cases provide a means of obtaining practice in doing this that they enjoy advantages over other more traditional methods, such as lectures and seminars. Since this is such an important attribute of cases, it is one that deserves to be treated in more detail.

Any such treatment must start with recognition of the self-evident fact that the task of the manager is essentially a problem-solving one. Whichever way you look at it, every manager must be able to diagnose situations, compare alternatives, and then take decisions that lead to goal attainment. Now, a distinguishing feature of what is taught on management programmes is that the content is (and must be) in the form of ideas or concepts based on carefully explored situations and samples. The trouble, of course, is that this sort of information is not really of much value unless managers are able to use it to help them make more effective decisions. In order to do this, they must be able to leap from the concepts or ideas to their application in the various problem situations that constitute their jobs. In trying to fit ideas or concepts to the various situations of their jobs, practising managers are confronting the problem of the relation between the general and the particular that has long troubled philosophers. It is no good for management courses simply to concentrate on the former - informing students of the available ideas or concepts that are felt to be relevant if they neglect the separate but related task of helping managers to apply such concepts to the kind of one-off situations they face on the job.

The reason why cases can help in this latter task is that they are reports of actual, unique, concrete problems or situations in particular organizations that require for their solution the application of the relevant concepts or ideas. They cannot be solved, or even properly examined, without a grasp of the appropriate concepts or ideas that make the case what it is. On the other hand, without constant application to problems that have to be solved in this way, the ideas or concepts remain worthless and just of academic concern. They only take on significance and acquire worth if they are constantly employed to analyse and solve the sort of problems that are likely to occur on the job.

It is only if students not only learn the relevant ideas or concepts, but also attempt to employ or use them in various contexts, that they will develop those skills of diagnosis and application that are the hallmark of the successful manager. At another level, it is only by moving backwards and forwards between the diagnosis of particular cases and the application of general concepts or ideas to them in this manner, that the problem of the relation between the general and the particular is directly confronted and overcome, by using each to make sense of the other.

What critics of the case method often fail to appreciate 
is that cases are not meant to replace knowledge of ideas or concepts, or to be used instead of learning about the latter. In earlier times, there was a tendency for entire courses to consist just of cases and nothing else. The idea was for students to work their way through a large number of cases and to form their own 'currently useful generalizations' from them. Underlying this way of using cases was the assumption that research had not established sufficient knowledge about management for a set of tested generalizations and even methods to be offered to students. A course of this kind is clearly a-theoretical and, in my view, is rightly criticized on many grounds. But more to the point is that few, if any, case-based courses that can be found in the modern business school can be characterized in this way. Since the 1950s management research has made great strides to the point where it is widely accepted that today we do possess some wellfound ideas and concepts that assist managers in analysing and solving problems. It is therefore important for courses to recognize this and to teach this important and useful knowledge. This is typically done. As a result, most case-based courses do not consist only of cases but also expose students to the relevant ideas, theories, concepts and analytic methods that have emerged from management research. In effect, the old-fashioned pure case course has become a mixed 'cases and concepts' course which typically relies on other methods as well as cases, to teach diagnostic and application skills that are essential for managerial success.

As a glance at any recent casebook (for example, Cohen et al.'; Armstrong ${ }^{\text {? }}$ ) will show, emphasis is on using cases to improve both the students' grasp of the ideas and concepts, and their capacity to use these in the solution of real-life problems. My argument in this paper is that cases are one of the most wide-ranging and powerful tools for achieving these twin goals, but that cases like any other tool are not unconditionally best under all circumstances. While it is my contention that cases are usually better than other available tools for achieving these goals, their effectiveness is contingent upon a number of considerations, deriving chiefly from the course objectives, the institution and programme environment of the course, and the staff and students involved. The elucidation of the precise conditions under which cases are maximally beneficial is a task for future research. However, in the light of the argument which has been developed so far, it is only in very extraordinary or unusual circumstances that other methods will be found to be generally better than cases in helping students grasp the appropriate concepts and ideas and apply them in such a way as to improve the likelihood of them doing so successfully back on the job.

A major reason for this view is that cases, more than any other method, place students in exactly the sort of situations they will encounter in their managerial jobs. While cases differ widely in a number of ways, they all require - as a condition of being cases - that students simultaneously cope with a variety of forces in complex inter-relationships. In this respect, they differ widely from the necessarily simplified and restricted situations that form the basis for survey and experimental research in management. Moreover, in this requirement they are forcing students to do precisely what they are called upon to do in their managerial task - to take into account a multitude of factors at the same time - in working out what to do in any given situation. Two further conclusions follow from this, both of which highlight the unique role of cases in management education.

\section{Unique benefits of the case method}

First, it is essential that managers have a state of mind which is alert and adaptive in seeking solutions to problems characterized by the complex interaction of a multitude of factors. A fertile field for concepts that can at least handle such problems is 'open systems' theory (see Kast and Rosenzweig'; Schein ${ }^{19}$ ), specifically developed to deal with multivariate problems that are organic rather than mechanistic in nature. It is because cases provide 'photographs' of genuine multivariate problems experienced by organizations that they are especially appropriate for practice in using concepts derived from the open systems theory or framework. Second, because they require students to understand concrete situations involving many variables, cases necessarily force the synthesis of a variety of ideas and concepts, often derived from different sources. In addition, and for the same reason, they necessitate the 'pulling together' of ideas or concepts that may otherwise appear unrelated or even conflictual. The case method, therefore, cannot be a respecter of traditional boundaries of academic disciplines - just as the effective manager cannot be. This is an important feature of cases that should not be underrated, especially in the South African situation, in which some academics claim that management is really only applied economics, applied psychology, or applied sociology, and that there is nothing distinctive to it.

It is to the credit of the case study method that it naturally draws attention to the unique integrating feature of management, as a discipline with the distinctive feature that it cuts across traditional boundaries. It forces recognition of the fact that at the heart of the management process lies the 'pulling together' of what different sources can contribute to the solution of specific problems. The case method, because of its peculiar qualities to which I have referred, provides the most effective means of making management education more whole and more distinct from the older disciplines like economics, psychology and even accounting, with which it has strong links. This is necessary because, after all, management is a distinct activity obviously different from applied economics, industrial psychology or practical accounting. "

A major reason why cases must form the most important element in any management programme is that managing has to do with problem-solving rather than just learning to do things. As a number of writers on management (for example, Barnard ${ }^{12}$; Drucker ${ }^{4}$; McGregor ${ }^{5}$ ) have made very clear, in managing we are engaged in a never-ending process of problem-solving, that can perhaps be conceived of as a four-stage cycle.

As indicated in the diagram, this cycle - which represents what managers are doing all the time - is characterized by four stages: (1) concrete experience, followed by (2) observation and reflection, which lead to (3) the formation of concepts and ideas, as well as limited generalizations, which lead to (4) hypotheses to be tested 


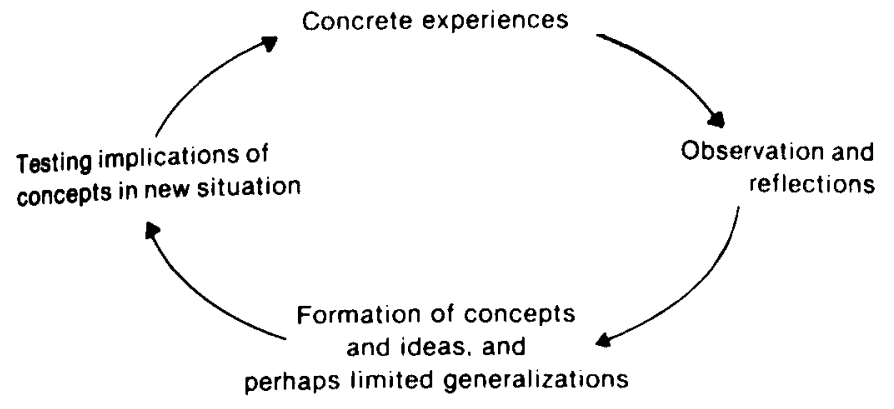

in future action, which in turn lead to new experiences. The point to be stressed is that we are dealing with a closed loop in which each stage leads to the next: managers continuously test their concepts in experience and modify them as a result of what they learn in this process of testing.

A major benefit of the case study method is that it directly assists students or managers in moving quickly and surely through the four stages of the cycle. The very nature of cases is such that a series of cases presented in the appropriate order requires managers or students, in working through the cases, to engage successively in a concrete experience (the initial case) from which they inductively derive concepts and ideas, and perhaps even limited generalizations which, once formed, lead to hypotheses whose implications are then tested in a new experience (the second case), and so on. In contrast, a major drawback to the traditional lecture/seminar method is that it is seen by students as standing outside this continuous four-stage cycle. It does not directly engage students in the process of actively testing out their ideas and concepts, and then modifying them on the basis of what they have learnt. In a sense, traditional methods try to teach the students too much, leaving insufficient room for students to find out by themselves, by engaging in action.

It is appropriate at this point to draw attention to two features of cases that have been the subject of criticism, whereas in reality they constitute two powerful reasons for their effectiveness: the fact that few, if any, cases contain all the data relevant to a perfect or thorough-going analysis; and conversely, the fact that many cases appear to contain a lot of irrelevant data.

To take the first point: Paradoxically, the fact that cases typically provide insufficient information is a strength - or at least a 'weakness' that reflects the reality of the manager's job. Unlike researchers who can afford to postpone judgement until they have collected enough data, managers seldom, if ever, can afford to do so. Although they may not have all the information they may consider relevant to making a particular decision, managers have to analyse the situation, make what decision they think best, and then act in the way indicated by their decision. Looked at from this point of view, the demand for more information can be seen for what it often is - a decision against taking any action at all. In managerial life decisions have to be made and action taken, often within severe constraints imposed by time and money, and hence information.

As regards the second point: as mentioned before, some people have criticized cases from the opposite point of view, claiming that they often present much more in- formation than is needed. Surely, it is argued, it is unreasonable to expect students to study 15 to 20 pages of text and tables thoroughly for one discussion. The resulting discussion must be unmanageable, it is claimed, because of the sheer quantity of irrelevant and redundant information that has to be sifted through. What such critics overlook is that in many situations managers face this problem of information overload, and have to spend as much time deciding which of the information is irrelevant, as actually analysing that data which is relevant to the problem at hand. In this respect, long cases do realistically represent a common managerial predicament.

It is much too easy to dispose of cases by claiming that brief cases are too superficial to be really useful, and long ones too complicated to be manageable. In actual fact, what is required is a mixture of long and short cases that represent the sort of on-the-job situation that most managers face. The very fact that they are short, gives some cases their advantage, since it reflects a common situation in which managers have to rely heavily on inference and a reading of symptoms, because of a scarcity of information. Conversely, it is precisely because they are long, that other cases are useful, since they require managers to eliminate or simplify data that are either unnecessary or too complicated - something they often have to do in their daily working lives. The real issue about long and short cases thus becomes one of deciding at a particular point whether to get students to 'work through' one or other of these kinds of cases.

\section{Teacher resistance to case method}

A major problem to be overcome in getting the case study method as widely adopted as it should be, is that of teacher resistance. This is likely to come from two sources. First, there are those teachers who seriously believe that the traditional lecture is the most effective way of teaching students what they need to know. Second, there are those who, while they may not hold this view, have simply grown accustomed to lecturing and find it difficult to teach in any other way.

The difficulty in getting such teachers to adopt the case study approach is that it makes quite different demands on the teacher than does reliance on the orthodox lecture. For one thing, it is not possible for the lecturer to talk authoritatively about matters the students have not heard about (as in lectures), since it is the very nature of cases that all members of the class - the teacher as well as the students - possess the same information (the case) which they have all presumably examined and analysed prior to the classroom meeting. For another, there is not just oneway communication from active teacher to passive students (as in lectures), since cases require most of the interpretation to come, initially at any rate, from the students and not just from the lecturer, thus forcing communication to be two-way rather than just one-way.

In case discussions, the lecturer acts more as a facilitator, keeping discussion going and within certain bounds, than as a provider of specialized knowledge. The burden of interpretation is placed on members of the class who thus do most of the talking, often strenuously disagreeing with the analyses of others, and trying to convince them of the merits of their own position. The result is a hubbub 
and untidiness, characteristic of genuine two-way communication. In contributing to such discussions, students gain valuable experience in expressing and defending their own points of view and listening to those of others - both skills that are required of effective managers. While this kind of discussion does provide an added advantage for the case method, it also often serves to frighten off traditionally-minded teachers.

Although the movement away from the lecture method to the case study method is often difficult to accomplish, it is one that has to be made. After all, management is ultimately about doing the right thing in the circumstances - something learnt by doing cases, not by just digesting ideas from teachers. Moreover, for management to be more than just a rag-bag collection of bits and pieces from 'proper' subjects, it needs to become more integrated - again something provided by having its own distinctive method, that provided by cases. For these reasons, cases need to be much more widely used and lectures much less so, if the teaching of management is not only to be effective but also to enjoy the distinction and status it deserves.

\section{References}

1. Campbell, J., Dunnette, M.D., Lawler, E.E. \& Weick, K. Managerial Behavior, Performance and Effectiveness, New York: McGraw-Hill, 1976.

2. Leavitt, H.L. Managerial Psychology. Chicago: University of Chicago Press, 1978.

3. Likert, R. New Patterns of Management. New York: McGrawHill. 1967.

4. Drucker, P. The Practice of Management. London: Heinemann, 1954

5. McGregor, D. The Human Side of Enterprise. New York: McGraw-Hill, 1960.

6. Dalton, M. Men Who Manage. New York: Wiley, 1961.

7. Cohen, A.R., Fink, S.L., Gadon, H. \& Willits, R. Effective Behaviour in Organizations: Learning from the Interplay of Cases, Concepts and Student Experiences. Homewood, III.: Irwin, 1980.

8. Armstrong, M. Case Studies in Management. London: Kogan Page, 1979.

9. Kast, F. \& Rosenzweig, M. Management: A System Approach. New York: McGraw-Hill, 1978.

10. Schein, E. Organizational Psychology. Englewood Cliffs, N.J.: Prentice-Hall, 1979.

11. Minzberg, H. The Nature of Managerial Work, pp. 51-62.

12. Barnard, C. The Functions of the Executive. Cambridge, Mass.: Harvard University Press, 1938. 